\title{
Tourism potential and rural tourism: A case study of the Municipality of Andrijevica
}

\author{
Goran Rajović $^{1, *}$, Jelisavka Bulatović ${ }^{2, * *}$ \\ ${ }^{1}$ Street Vojvode Stepe 252, Belgrade, Serbia \\ Phone: 0038161/19-24-850 \\ ${ }^{2}$ Department of Technology and Management, College of Textile Design, \\ Street Starine Novaka 24, Belgrade, Serbia \\ Phone: 003861/ 3082651 \\ ${ }^{*, * * E-m a i l ~ a d d r e s s: ~ d k g o r a n . r a j o v i c @ g m a i l . c o m ~, ~ j e l i s a v k a . b u l a t o v i c @ g m a i l . c o m ~}$
}

\begin{abstract}
The paper analyses tourism potential and rural tourism of the Municipality of Andrijevica. Existing tourism and recreation supply is not sufficiently developed and affirmed nor organized and connected both within the scope of the Municipality and with the neighbouring municipalities. One of the prerequisites for tourism development might be good transport infrastructure. However, in the territory of the Municipality of Andrijevica is not adequate. On the territory of the Municipality of Andrijevica, natural and anthropogenic values are distinguished group deployment and characteristics of complexity and complementarily. Natural values are particularly come to the fore, if we know that modern tourism trends emphasize the value of untouched nature. Marketing affirmation of the Municipality of Andrijevica is one of the most important processes that represent a momentum for its tourism development. In this sense, all kinds of tourism propaganda must be enhanced, which affirmed the value of tourism (for example the eco-pasture Štavna), which would lead to a more comprehensive tourism development that would provide a profitable economic performance. Particularly it is very important to encourage and support rapid development of economic activities in rural areas and development of human resources. Furthermore, the economic progress and independence rural settlements of the Municipality of Andrijevica must be improved in accordance with the ecological principles and sustainable development in rural development. In finding a new identity and direction of development of the rural economy, the Municipality of Andrijevica must accept new trends in Europe and the countries that have been through a period of transition, in terms of adapting and complementing so far the role of villages and rural areas within diversified supply and the introduction of tourism as one the essential activities. Such guidelines already exist in spatial and urban plans of the Municipality of Andrijevica, starting as of 2010.
\end{abstract}

Keywords: Municipality of Andrijevica; natural features; social features; rural tourism

\section{INTRODUCTION}

From the point of research in tourism, our research evidence, based on similar studies Plavša and Ratković [1] stressed it to the forefront the obvious fact that are rural areas of the Municipality of Andrijevica relatively little studied. At a time when most of the rural settlements of Montenegro including the rural areas of the Municipality of Andrijevica, engulfed the process of depopulation occurs the one new alternative, which can stop or 
mitigate this process. Rural tourism as a specific form of tourism has a bright future exactly in these areas. The effects of urbanization were arriving in the area rural settlements in the Municipality of Andrijevica very slowly. This is in large measured and resulted in the preservation of traditional ways of life population in rural settlements. It is precisely this characteristic that became a critical factor for development of rural tourism in the Municipality of Andrijevica. If we consider that rural tourism should be based primarily on the rich natural heritage, unpolluted rivers, diverse flora and fauna, temperate continental climate, as the main motivating factor to attract large number of tourists, but also an equally important cultural and historical heritage.

According to Živanović and Pantić [2] the rural development is the key instrument in the restructuring of agricultural sector and should be tasked to direct strategic use of potential attractive tourist village. For this reason, these specifics should recognize and use them as instruments for alternative economic activities in rural areas. At this time, encouraging and supporting rapid development of economic activities in rural areas and the development of human resources, as well as economic progress and independence of rural communities, in accordance with the principles of environmental and sustainable development in rural development is of crucial importance. Considering the current situation where there is majority of rural settlements in the Municipality of Andrijevica, "strategic exploitation of tourism potential of rural settlements would include: utilization of excess housing, employment of available human resources, attracting new workers returning youth to the countryside, selling their own agricultural and other products to a higher stage of processing without cost of transportation, lease of retail space, expenditure of time and energy by favourable prices create better living conditions for those remaining in rural areas, through rural development and raising the living standards to the desired level, formation of a new family business, better use of existing resources and their development guidance to new needs, the development of new and better utilization of existing ability of household members" [2].

\section{RESEARCH METHODOLOGY}

This research aims to provide a review of tourism potential of rural tourism in the Municipality of Andrijevica. The objective of this study is to apply combined use of different research methods. The core methodological procedure used in this study is the geographical (spatial) method, whose scope of research is related to the Municipality of Andrijevica. It is in fact geographical unit which comprises $2,46 \%$ of the total area of Montenegro (13.812 $\left.\mathrm{km}^{2}\right)$, that is, living in the territory $0,86 \%$ (5.785 population) of the population compared to the total population of Montenegro in 2003 (673.094) [3]. During the research, we have used the following methods: descriptive, causal, comparative method and theoretical analysis. Descriptive and causal methods were used to detect the cause consequential link between tourism potential of rural tourism in the Municipality of Andrijevica.

The methods of theoretical analysis encompassed theoretical basis of the research. The combination of these methods is possible to validly define the achieved research goals, which refer to the basic natural and social characteristics of the considered geo-space and opportunities for rural tourism development. For the data collection related to the analysis of population and settlements, we used the statistical method, i.e. the data from the State Statistical Office of Montenegro [4]. Furthermore, we have studied many written documents from the internet. In the scientific explanation of terms, we have applied two methods: the 
method of analysis and synthesis methods. By introducing the method of analysis, we were able to deconstruct the complex notions and courts in research and bring out conclusions to their simpler components. The synthesis methods were included as a way of systematization of knowledge according to the laws of formal logic, and process of theoretical knowledge in the direction of specific to general [5].

\section{ANALYSIS AND DISCUSSION}

\section{1. Natural characteristics}

Analysis characteristics of relief, climate, hydrological characteristics, soil and flora and fauna, one can estimate the natural potential of certain economic activities, especially tourism. Andrijevica is municipality located in the north-eastern part of Montenegro. It covers an area of $340 \mathrm{~km}^{2}$. In this area according to the census in 2003, lived in rural areas were 4.592 residents, or 14,1 inhabitants $\mathrm{in} / \mathrm{km}^{2}$. Otherwise, the total population in the municipality is 5.785 or $20,4 \mathrm{in} / \mathrm{km}^{2}$. The Municipality of Andrijevica borders to the north and east with the Municipality of Berane, to the southeast with the Municipality of Plav, to the west with the Municipality of Podgorica and Kolašin and to the south with the Republic of Albania [6]. The Municipality of Andrijevica has a peripheral geographical position, since in this region do not cross the road, with bond functions in the organization of space in the Republic of Montenegro. The backbone network consists of two travel routes.

The first is a section of the highway M-9: Kolašin - Mateševo - Andrijevica-Murino Peć. The second route is a section of the regional road R-2: Berane - Andrijevica. Highway M-9 extends a distance of $31 \mathrm{~km}$ and passes through five rural settlements of the Municipality: Gnjili Potok, Sjenožeta, Kralje, Gornje Luge and Ulotina. The regional road R2 provided through the valley of the River Lim in length of 7,9 km and Berane passes through or near a rural village: Prisoja, Slatina, Trešnjevo and Marsenić Rijeka [7]. The categorized road network in the Municipality of Andrijevica has a total length of about $113 \mathrm{~km}$, which represents approximately $1.5 \%$ of categorized road network of Montenegro $(7.368 \mathrm{~km})$. One indicator of development of road network of Andrijevica is the density of road network, which is $39,8 \mathrm{~km} / 100 \mathrm{~km}^{2}$ and is significantly below average compared to the density of road network in Montenegro $\left(53,3 \mathrm{~km} / \mathrm{km}^{2}\right)$. The isolated traffic and geographical position of Andrijevica adversely affect its economic and social development.

The Natural terrain features are the basis of existence and progress of each geospatial unit. The distribution of natural resources is a measure of opportunity to develop a specific territory. The natural resources of rural settlements of Andrijevica challenge for understanding the possibilities of development of certain economic activities, particularly agriculture, tourism and construction. The geo-morphological territory of Andrijevica is the mountainous character. Height difference between the highest (Kom Vasojevićki $2.461 \mathrm{~m}$ ) and lowest (at Navotine $700 \mathrm{~m}$ ) is $1.761 \mathrm{~m}$. Thus, forms of relief in height and configuration, exposed slopes, and under the influence of different features of the surface (forests, meadows, litisoli, fields, and orchards), based on diverse natural, and which may be of importance for the development of agriculture and tourism. The most widespread and most important geomorphologic travel motif of Andrijevica represents Bjelasica and Komovi. Namely, the Municipality of Andrijevica covers parts of Southeast Bjelasica mountain ranges where peaks stand out: Troglav $(2.072 \mathrm{~m})$, Jelenak $(1.887 \mathrm{~m})$, Lisa $(1.878 \mathrm{~m})$, Pobodenjak $(1.839 \mathrm{~m})$, Zminja Glava $(1.733 \mathrm{~m})$, Rudo Brdo $(1.649 \mathrm{~m})$ and Žoljevica $(1.510 \mathrm{~m})$. The massif is Bjelasica Trešnjevik over the saddle $(1.573 \mathrm{~m})$, associated with massive Komovi, where in 
addition to the Municipality of Andrijevica Vasojevićkog Coma, are Bavan (2.252 m), Štavna $(1,828 \mathrm{~m})$, Carine $(1.987 \mathrm{~m})$ and Ogorela glava $(1.561 \mathrm{~m})$. In the south of the border with the Republic of Albania are Klaja Zabeljit $(2.130 \mathrm{~m})$, Mojan $(2.157)$, Ilijina glava $(2.165 \mathrm{~m})$, Žijova glava $(2,129 \mathrm{~m})$ and Biograd $(2.123 \mathrm{~m})$. In the south-eastern part of the south-western municipality of intervention, western and north-western parts: Visitora with Lipovicom $(1.882 \mathrm{~m})$, Grebenom $(2.196 \mathrm{~m})$ and Zeletinom $(2.126 \mathrm{~m})$. To the east of the Municipality is tipped Balj Teferič $(1.557 \mathrm{~m})$. Mountain ranges split and cut the number of river valleys that deeply cut into their beds, in places, and building a real cliff. The most important is certainly the Lima valley, which has a significant expansion, in places where the Lim its tributaries flow [8-10].

Thanks to the geological structure in the municipality are Andrijevica ore metals: lead, zinc, copper, iron and pyrite (Dulipolje, Zabrđe, Sjekirica ...). Of non-metallic mineral deposits, occur in building materials: gravel, sand and decorative stones. Numerous deposits of gravel and sand found in the bed are of the river Lim. Only in Bandović Bridge, the amount of gravel and sand, available for the annual extraction estimated at about 100 to $120.000 \mathrm{~m}^{3}$. On the hill Žoljevica, there is slot architecture - building stone. The estimated reserves of grey marble $\mathrm{B}+\mathrm{C} 1$ category, amount to $2.223 .000 \mathrm{~m}^{3}$, a reserve of white and grey-white marble belonging to the $\mathrm{Cl}$ category is $60.000 \mathrm{~m}^{3}$. When it comes to the exploitation and processing of marble and ornamental stone, it should noted that there are multiple sites of different architectural building stone and marble, of which the most significant site Trebačka River, Seoce, Piševska River, stream Babovog, Pčelinjak, Žoljevica [11-12].

The Municipality of Andrijevica has a moderate continental climate, with some elements of sub mountainous and mountainous. As the measurement of meteorological elements performed only in Berane and provides a basis for conclusions about the state of is running climate in the municipality Andrijevica. The mean annual air temperature is $8.0{ }^{\circ} \mathrm{C}$. According to a vertical gradient with the increase of altitude, mean annual air temperature is lower and amounts to $1.000 \mathrm{~m}$ above $7.0^{\circ} \mathrm{C}$ at $1.200 \mathrm{~m}$ above $6,4^{\circ} \mathrm{C}$ at $1.400 \mathrm{~m}$ above $5,8^{\circ} \mathrm{C}$, at $1.600 \mathrm{~m}$ above $5,2{ }^{\circ} \mathrm{C}$ at $1.800 \mathrm{~m}$ above sea level is $4.6{ }^{\circ} \mathrm{C}$ at $2.000 \mathrm{~m}$ above $4.0{ }^{\circ} \mathrm{C}$. Absolute maximum temperature in July and is $32,6^{\circ} \mathrm{C}$ and an absolute minimum in January is $-19,4{ }^{\circ} \mathrm{C}$. The mean annual relative humidity is $67 \%$. In summer, (July and August) monthly mean relative humidity in the afternoon (14h) is below $45 \%$, and in April below $63 \%$. Cloudiness has an average annual value of $9,0 / 10$.

The minimum average coverage of the sky in July and is 4,4/10. Average annual rainfall is around $1.152 \mathrm{~mm}$. The least amount of rainfall in September $(47 \mathrm{~mm})$ and August $(54 \mathrm{~mm})$, while the highest rainfall related to the period from October to December $(96 \mathrm{~mm}$ to $107 \mathrm{~mm}$ ). Prevailing winds in the winter months the north-west and north, and in other months of the south wind. North and northwest winds, bringing dry and stable time, perfect for tourism are during the summer and winter. Winds from the south direction diversified in the winter, when making a significant amount of snowfall [13].

The hydrographic features profile a variety of important water resources, as well as natural wealth. In terms of hydrographic, the Municipality of Andrijevica belongs to a highly developed hydrographic network. In this sense, in the municipality, there are obvious power potential of the Lim River and its tributaries (Piševska, Šekularska river, which originates from Zlorecica Perućica and Kutski River, which originates from Kraštica Rajovi river, Trebačka ...). Besides these, there are numerous smaller streams, especially in rural settlements: Gnjili Potok, Kralje, Ulotina, Gornje Luge, Zabrdje, and Trešnjevo. It is height position of rural settlements, with emphasis on the aspect valorisation importance of water 
management and groundwater. In other words, the use of groundwater for water supply of rural heritage is of crucial importance. Thus, from the source "Krkori" located in the area of rural settlements Kuti, water supplies in addition to urban and rural settlements Andrijevica: Đuliće, Bojoviće, Seoce, Božiće, Prisoja, Slatina, Zabrđe and Trešnjevo. Water as natural resources, have a range of options from the standpoint of - of hydro potential, market valuation and ecology. The economic use, protection and rational approach to water resources, can have very positive effects in the future development of rural settlements of Andrijevica [14-16].

In the area of Andrijevica represented between the two types of land cover lines and automorphicto hydromorphic soil and its variations. The first class includes land automorphic undeveloped and underdeveloped land (A - S profiles): litisoli, regosols and colluvial deposits. For the second class (A-S profile) automorphic soil characteristic is continuously developed and conspicuous morphological humus horizon. This class consists of four types: mountain soil, land on marl, limestone and dolomite, rankers and vertisols. The third class consists of land automorphic land (A-(V)-S) and (A-(V)-R) profile is characterized by the appearance of the horizon (V), which sits on the loose substrate or on a compact system. Within this class is representing by three types of land: eutric camisoles, district cambisol and calc-camisoles.

The fourth class consists of eluvia soil - soil illuvials (A-E-V-S, or A-E-V-R) profile: luvisol, podsol and brown podsol soil. As a special class of automorphic anthropogenic land set aside the land that, the treatment has changed its original status. Second row (row B) is hydromorphic soil: epigley, hypogley, alluvial soil and peat. The first category consists of land epigley hydromorphic soil, represented pseudogley and stagnogley. The second class of hydromorphic soils is represented by land: hipogley, enegley, and semigley and amfigley land. The third class consists of hydromorphic soil fluvisol, hums fluvisol. Fluvisol is the most important agricultural production value and type of soil is mostly prevalent along the river valleys. Hums fluvisol as independent genetic type of soil has a profile (A-S-G). The fourth class of hydromorphic soil makes one type of land - lowland required. Relief formed in depressions in which water constantly stagnates above the ground. It is located about Bukumirsko lakes [17].

For the appearance of the landscape of Andrijevica, is of particular importance biogeography characteristics. Flora consists of forest and grass vegetation. In the lower parts of trees are represented hydrophilic willow, poplar, alder, hornbeam, oak, oak, beech, birch, maple. The belt of beech is most common in the form of four regions: mountain beech (at lower altitudes), mountain beech forest at height 1.000-1.300 m above sea level, sub alpine beech forest at altitudes greater than $1.800 \mathrm{~m}$ spruce dominated by forests. With some of the mountain, high mountain forests stretch, White Bark Pine and white bark pine. Above this band is representing by white space and black pine. Some forest stands and makes the dwarf pine, whose propagation exceeds $2.000 \mathrm{~m}$, and juniper pine, which ends above $2.200 \mathrm{~m}$. The share of forests in total area of Andrijevica is 13.912.80 ha. Regarding the breeding categories, dominated by commercial forests. Of the total area, the forest industry are waste 7.687.02 ha, and 25.805 ha of forest low. Forests for other purposes and barren forestland are covering an area of 5.806 .23 ha.

The total density is $3.284 .660 \mathrm{~m}^{3}$. Annual growth forests estimated to be $44.817 \mathrm{~m}^{3}$. Taking into account the habitat conditions and photos sociological composition, grass cover of Andrijevica can be divide into the damp valley meadows habitats, mountain (mountain) meadows and pastures mainly related to the belt of oak forests and mountain pastures that reach the highest peaks of the mountains. Flora of forests and pastures enriched with various 
kinds of herbs and edible fungi. Most of them occupy a high place in folk medicine, pharmaceutical production, which is very important for the tourism development. Herbs rich in its diversity, physiological and pharmacological action, and a healthy quantity of raw materials, offers unimagined possibilities in the development of health and educational tourism.

The most important species of medicinal plants from the commercial aspects are yarrow, thistle, birch, hawthorn, horsetail, cranberry, gentian, wild thyme, omen, blueberries, mint, blackberry, raspberry, dandelion, thyme and nettle. Of forest products: hawthorn, juniper, strawberry, cornelian cherries, blackberries, raspberries, blueberries, saffron, rose hip, and mushrooms: porcini, black trumpet mushrooms. However, the most important product makes are blueberries which reach its annual purchase of about 100 tons. Thanks to the widespread forests, pastures and meadows are diverse landscapes and picturesque, which provides significant environmental and tourism values and makes an attractive area of Andrijevica. Meadows and pastures covered with succulent grass and mountain meadow flowers, so that together with forests, providing a unique land scape decorative value. The belt of forests is particularly interesting as living space varied wildlife, birds, fish and insects that are. Is the pearl of the unique natural beauty and a spoilt nature? From the aspect of tourism resources and has considerable potential for developing different types of tourism such as hunting, fishing, adventure, adrenaline [18].

\section{2. Social characteristics}

\section{2. 1. Review on short history of Andrijevica}

The Municipal Centre of Andrijevica is a relatively new settlement, because it's the first beginnings started only in mid nineteenth century. This does not mean that the territory of the municipality was of always space of human activity and space with economically active areas, which are in a lull, was developed by or disappeared onslaught of invaders. Archaeological investigations of the Institute for Protection of Monuments from Cetinje in 1956, found that traces of material culture from the Neolithic are in the valley of Berane. Except mentioned they found traces of Illyrian material culture, so it is likely that the environment Andrijevica ecumenical space of all ancient peoples. They were discovered and numerous sites of Roman settlements in the area Andrijevice. On Roman are necropolises of found several monuments. It is particularly well-preserved monument in the village Zabrdu, under Žoljevica. Based on this evidence it can be concluded that the area of Andrijevica was socially economically active from the earliest times [19].

Southwest of Andrijevice, at a distance of $1 \mathrm{~km}$ to the village of Božiće, findings the rise Grace, where is in the Middle Ages existed fortress - the city what the name suggests. Even today, was a noticeable area where the fort, which had a strategic importance at the crossroads of the Lim River and its tributary Zlorečica. These routes were an integral part of the main road between the old Raška and Zeta. A number of medieval monuments: charter of, documents, chronicles, records, registered a larger number of villages that are still present in the background Andrijevice and which are undoubtedly older than the municipal centre. It was noted that the area Municipal Andrijevica was densely populated Serbian population in the age Nemanjića, and that the centre of gravity was Buda city in Budimlja district, $15 \mathrm{~km}$ away from Andrijevice and its environment [20]. According to the Rome Charter of the eighth century; Komski district and the respective parish, were given to Rastko Nemanjić and descendants Miroslav Nemanjića, and his son, Andrew, Zahumlje prince raised into his glory church between the rivers, (The old Andrijevica). 
The church had Andrijevna is workshop carved wooden character, but with the arrival of the Turks repeatedly burned, destroyed and rebuilt that would the ultimate dissension has experienced During the year 1765 visit Kariman - pasha, who burned all the villages in the district Komskoj. In the later period in 1853, an old Serbian tribe Vasojevići he lifted is often revolts against Turkish rule, started and to be developed a village around the church Andrijevna by whom is and received name Andrijevica.

In 1858, prominent Duke Tribes Vasojevića Miljan Vukov proclaims Vasojeviće integral part of Montenegro [21]. As of 1878, Andrijevica becomes the political kernel the entire northern Montenegro. In this time of it is being developed in several directions. Besides military functions, Andrijevica acquire and administrative-management, trade, and the opening of school, educational and cultural. So is Andrijevica until 1912, expanding the along main road Polimlja on glacial fluvial terrace above the river Lima, obtained the physiognomy of the borough. Development of the area and town is interrupted during Balkan wars and the First World War that would only after the liberation of the Austro-Hungarian originated her significant development. Immediately after the First World War II, Andrijevica is regional place with four districts: Andrijevica, Kralje, Lijeva Rijeka and Plav - Gusinje. Abolition district from 1921 to the Andrijevica becomes regional place for all the above mentioned districts. And after the Second World War in Andrijevica is any seat district until the 1951 encompassing great gravitational range: Lijeve Rijeke, Mateševo, Bare Kraljske, Valley Plav - Gusinje valley, Trebačka-Šekular municipality and the of course the present municipal area. In time between the two worlds wars Andrijevica experiencing the most remarkable development.

Becomes are major administrative, managerial, economic, cultural and educational centre of north-eastern part of Montenegro. Act on the basis of social and political order People's Republic of Montenegro of 22 July 1957 abolish are districts and ceased to exist on 1 January 1958. Since then, Andrijevica is a municipality all to adoption of the new Law on the division of the People's Republic of Montenegro to the municipalities. That Law on 15 April 1960, Andrejevica has lost the status of a municipality, its territory was divided and assigned the neigh boring communes, all administrative and management functions, economic, educational, cultural actors in outsourced to municipality Berane [19]. Exactly after 30 years of abolition municipalities, Parliament of Montenegro again the adoption of the amendment "Law on Territorial Division of Montenegro on Municipality" returned to the status of municipality Andrijevica and in 1991 again formed assembly Municipal Andrijevica and its executive organs of local government.

\section{2. 2. Population}

The number of inhabitants in Andrijevica is constantly decreasing. In the beginning of 1948, when is on census there were 10.058 people, on each successive census, the number had decreased (1953-10.267, 1961-9.791, 1971-9.299, 1981-7,488, 1991-6.696). So is during the last Census of 2003, the Municipality of Andrijevica had 5,785 inhabitants, which is $43,66 \%$ less than in 1948. The average annual natural growth population in the period 19711981 is amounted to $-177,9 \%$, during the period 1981 to 1991 was $-79,1 \%$ in the time period 1991 to 2003 was $-75,9 \%$. The birth rate shows that are in 1998 the municipality Andrijevica are born 78 children, as of 1999 and (78). Number of live births children the has increased in 2000 on 84 in 2001 to 86 years, while in 2002 born 60 children. The mortality rate shows that in 1998 in the municipality of Andrijevica died 85 inhabitants in 199961 resident. The number of deaths increased in 2000 on 84 in 2001, a total of died 80 inhabitants, while in 2002 a total of 65 inhabitants died. The age structure of the population of the 
municipality Andrijevica, due to migration and reduction fertility the changes and takes on unfavourable characteristics - decreases the share younger, and increasing the proportion of the elderly population.

In both cases, disturbed age structure has feedback influence on the movement of the population (the size of reproductive contingent) but on all other population structure (the size of the workforce, active citizenship, schooling compulsory contingent ...) which are essential to the development of population and economic activity Municipal Andrijevica. In municipality Andrijevica can be observed phenomenon that more male than female population (2003). Namely in relation to the total population of 5.785 inhabitants of the municipality, men was 2.941 or $50.84 \%$ women's 2.844 or $49,16 \%$. The rate of masculinity shows the number of men per 1.000 women. According to the census of 2003 the rate of masculinity in municipality Andrijevica amounted to $1.034,1 \%$. The rate of femininity shows the number of women per 1.000 men. According to the census of 2003 the rate of femininity in municipality Andrijevica amounted to $967,0 \%$. The age-sex structure of the census of 2003 in municipality Andrijevica, visible is higher proportion of the male population to 65 and more year age, while the in other groups increased participation of women.

The age groups of the total population, on group of $0-14$ years accounted for $9.66 \%$ of male and 9,27 \% female population; $15-19$ years, $4,06 \%$ of the male and $3.49 \%$ were female; 20-39 years 14,75\% male and $11.60 \%$ female; 40-64 years 15,06\% male and 13,78\% female and 65 more year 7,31\% male and $11.03 \%$ female population. Literacy is one of the main indicators of the educational structure of the population. According to the census of 2003 in municipality Andrijevica a total of 173 illiterate populations, aged over 10 years. Of which are 146 women and 27 men. In comparing the age structure of the population was illiterate in 2003, it can be concluded that in total illiterate population in municipality Andrijevica, proportions of young illiterate population (10-19 years) amounts with men - \%, females $2.05 \%$, (20 - 34 years), men $7.41 \%$, women $2.05 \%$ (35-64 years), males $62,96 \%$, females 5,49\%, (65 and over) men 29,63\%, women $90.41 \%$. From the previous analysis shows that in the age structure of the population was illiterate, is predominant aging population. Educational attainment is another important indicator of the educational structure of the population, which is also unfavourable.

According to data for 2003 in the Municipality of Andrijevica - without any qualifications was 313 , or $6.69 \%$, incomplete primary education had 614 or $13,12 \%$, primary education 1,367 or $29,21 \%$ secondary education has 1.941 or $41,47 \%$ More education 190 or $4.06 \%$ and High 145 or $3,10 \%$ of the total population aged 15 and over. This educational structure of the population is unfavourable for any modernization of the economy in municipality Andrijevica [22]. Agricultural and non-agricultural population in the mutual proportion shows degree agriculture regression. The share of agriculture in total population of the Municipality of Andrijevica in 2003 was 485 inhabitants or $8.38 \%$, while the non-agricultural population consisted of 5.300 inhabitants or $91,62 \%$.

Total active population in the municipality Andrijevica 2.320 or $40.10 \%$ while is 2.365 inhabitants dependent or $40,88 \%$. With personal income were 1.079 inhabitants or $18.65 \%$. The ethnic composition of the municipal Andrijevica, the largest number of Serbs (4.027), followed by Montenegrins $(1,454)$ then Muslim (8), Yugoslavs (3), Macedonians (2), Croats (2), Slovenians (1), Hungarians (1), "other" (7), regional origin (2) not opted (216), not known (62). By household size municipalities Andrijevica is above average in Montenegro. So in the Municipality of Andrijevica are there is approximately 5 persons per household (2003 census), while in Montenegro about 3 members. 


\section{2. 3. Economy}

If we look at the period up to 1912, one can say that the Municipality of Andrijevica has been very underdeveloped. The main cause for this is historical events in this region and the peripheral position of the municipality through history in all countries, today and in Montenegro. In the Turkish time of here it was developed on a small scale manufacturing, trade and catering. After the liberation of Turkey until the end the Second World War, the economy is still in bad shape. Existed is agricultural production, but was based on outdated land cultivation and even that could not fix the economic picture municipal Andrijevica. Single most important event in economic development municipal Andrijevica after World War II was the firstborn of industrial non-metal industry - Marble "Komovi" started its operations in 1964. After the industry "Marble" an increasing share in the economic developments of Andrijevica gets the social sector. Enterprise "Termovent" was founded in 1972. Factory is "Soko Stark" in 1977. Paper Industry "paper products," 1984. Leather industry is represented by drive children, fur and leather products "Polimka" - Berane. The social economy has been in over $70 \%$ of the total national income of the municipality. However, after the collapse of the old Yugoslavia mentioned industrial buildings have found themselves in the economic collapse.

"The disintegration of the former Yugoslavia, the war in environment sanctions from the international community, the social and political changes, deep economic crisis, military intervention, political situation, the crisis, etc. Institutions, economic and existential uncertainty, the basic features of life in are nineties of the last are century, both on the individual and on a psychological level" [23]. In addition to industry municipality Andrijevica represented and agricultural production. However, agricultural production is done almost in a primitive manner and on small plots. Agricultural households (1.600) are mostly elderly, and the production is based only on meeting the needs of households without creating commodity surpluses for the market. The municipality has 5.971 ha of land suitable for agricultural production.

Forests cover proctor of 13.920 ha. In the Municipality of Andrijevica registered the "Association of Milk Producers," which has 70 members and "Beekeepers" with 64 members, and is planning to register the "Association of Fruit", which they established seedlings through economic development, funded by USID and the CHF. According to the Regional Business Centre Berane [24] economic activity in the area of Andrijevica performed within medium-sized enterprises, "FORESTS Company" - timber harvesting, "Poplar" - primary processing of wood, "May 1" - the turnover in wholesale and retail "Boj Komerc" production of timber, Hotel" Komovi" - providing catering and accommodation services," utilities "-the provision of utility services. In framework small business: in trade is 35 , in the area of hospitality 5. The municipality Andrijevica total of 97 entrepreneurs, of which: in field crafts 11,32 in commerce, 26 in the field of hospitality, in transport 25 . According to the data of the Statistical Office of Montenegro [4] total active population performed occupation in municipality Andrijevica in 2003 was 1,285 persons.

Of which in agriculture, hunting and forestry of the active population was 169 , in the fishing industry 2 mining and quarrying 4 manufacturing industry 247, production electrical electricity, gas and water 47 construction 29, wholesale and little 116, hotels and restaurants 65 , transport, storage and communications 80 , financial management 90 , real estate 8 , public administration and social security 231 . The number of unemployed people in municipality Andrijevica (number only registered), according to the Institute for Employment in 2004 was 762 , of whom 321 men and 441 women. 


\section{2. 4. Settlements}

The administrative and territorial structure of the Municipality of Andrijevica comprises of 24 rural villages and 25 cadastral municipalities $\left(340 \mathrm{~km}^{2}\right)$, where 23 villages of the districts make up the category to its geo-rural area, but the cadastral municipality Slatina I and Slatina II belongs settlement - Prisoja, while one village and cadastral municipalities Andrijevica, members of the urban environment.

Within the cadastral Municipality of Andrijevica located in addition to the aforementioned urban and two rural settlements - Andzelati and Božiće. In addition, the most recent statistical classification of settlements of 2011, amendments were made in the number of settlements in the municipality Andrijevica, so the town got Andželati new name Sućeska Andzelati, while was formed and a new rural settlement Navotina. Settlements municipal Andrijevica belong to the rarely populated rural areas (overall population density is 17,0 $\mathrm{in} / \mathrm{km}^{2}$ ), and the observed territory of the 25 C.M. (cadastral municipality) in 12 of them, the density ranges from 2 to $15 \mathrm{in} / \mathrm{km}^{2}$. According to the data of the Statistical Office of Montenegro (2005) on the territory municipal Andrijevica in 2003, Spotlight very small village (100 inhabitants) is in total 4 with 290 inhabitants then followed by small villages (from 100-300 people) them in total 14 with 2,048 inhabitants small medium settlements (range of 300-500 people) is 3 with 962 inhabitants and medium settlements (higher than 500 inhabitants) of 2 to 1.292 people.

According to "The spatial and urban plans of the Municipality Andrijevica" [8] of the Municipality of Andrijevica, the settlements have been grouped into five zones. North Zone includes settlements: Sjenožeta, Prisoja, Slatina, Zabrđe, Trešnjevo and Trepča within which the western and north-western part of extends massif Bjelasica is suitable for the development of forestry, agriculture and tourism. West Zone comprises settlements: Gnjili Potok, Kralje, Oblo Brdo, Božiće, Dulipolje, Košutići characterized by the development of tourism in (summer pastures Štavna, pasture Božiće, pasture Vulica ...) is suitable for the development of eco-tourism and hydropower development. The central area comprises municipal centre Andrijevica suitable for industrial development, social entrepreneurship, and cultural activities as well as tourism. East Zone includes the village Rijeka Marsenić, Seoca and Gračanica rich deposits of minerals and decorative stone and marble has the capacity development in these areas, as well as the development of mountain tourism, hunting and fishing.

The southern zone includes the settlements of Andželati, Bojovići, Upper Luge, Đulići, Cecune, Ulotina, Kuti and Jošanica is suitable for the development of mountain tourism, hunting and fishing, as well as for livestock development. Modern skid traffic and geographical position in relation to the economy is contained in the fact that with the exception of continental arm of the Adriatic Highway, none road Serbian-Montenegrin and European importance does not intersect or touches the municipality. Isolated traffic and geographical position adversely affects its economic and social development. Municipality Andrijevica is significantly distant of the major economic centres. Andrijevice distance from major urban centres (road distance) Podgorica 154 km, 231 km Budva, Herceg Novi 314 km, $396 \mathrm{~km}$ Belgrade. In such conditions, the gap between the existing natural resources and the level of development of transport there is more apparent. Reasons for it have more. The southern border area are state border according to Albania, other neighbouring municipalities have failed that these promote the itself and features, and of supplementing in terms of mergers and permeation of the Montenegrin coast are more take place with the economic centre of Podgorica and Nikšić as and Berane as a regional centre of north-eastern 
Montenegro as a competitive and attractive. Andrijevica not built bus station, while are stations intended travellers of modest dimensions.

The Bus transport is an important factor in the availability of services for the rural population of the municipality, due to the lack of availability of services, leads to that the smaller and more remote rural areas municipal Andrijevica tend to stagnation and depopulation. Bearing in mind bad transport connections within the residence municipality and the fact that the area is mostly mountainous and undeveloped becomes clear what led to the migration of people. On the territory municipal Andrijevica there is only one gas station, and one service dedicated technical inspection of vehicles. Bearing in mind the overall needs of the population of the municipality for these services, we can say that the situation is not satisfactory, both in terms of capacity and in terms coverage of the area.

\section{2. 5. Cultural assets}

Significant cultural and historical heritage of the Municipality of Andrijevica is not adequately valorised. With viewpoint of tourism is particularly important that the cultural heritage is largely spatially congruent with the major recreational and tourist areas and picnic areas and can be valorised, mastermind and represent as a very respectable factor for the development of tourism. Among the tourist potential anthropogenic municipal Andrijevica emphasizes the monumental heritage. The oldest part of our heritage (prehistoric, Illyrian, Roman) which are human hand with love and enthusiasm created, there exquisite beauty. The remains of tool, needles, awls, knives, bullet-proof shirt, ceramic arrows, spears and pipe parts, can become important forms of interest of local and foreign tourists [25]. A special group of tourist motives make memorial medieval church architecture - the Church of St. Michael the Archangel, and diverse memorial imprint (monument to Knjaževcu, memorial complexes and dozens of others across the municipality erected a memorial plaque, memorial statue, memorial drinking fountain ...).

Of all the existing cultural assets largest importance certainly has monuments to Knjaževcu. Deletić [26] points that are Knjaževac gate Andrijevice and the ID card overall Vasojevića. On the plateau above Lima, Crossed Arms are road and human destiny intermingled time in are past, graves, markers, events and memory. There are associated monuments from many wars for freedom. Among them is a unique monument to heroes of the Balkan Wars and World War. Besides monuments are and memorials to greats past Miljan Vukov and the abbot of Mojsije Zečević and monuments to Soviet soldiers who died in World War II. Possession in this sanctuary is dominated by on Knjaževcu temple built in 1887 dedicated Arhanel Michael, baptismal glory Vasojevića. Today is Knjaževac park where are admires every passer-by. Picturesque nature, historic landmarks and church built in the Byzantine style slightly what lures view of every passer-by, especially those from other areas. Here is according to Deletic [26] nature drowned in history and history in nature, and together challenge views of beauty and admiration. A lot of that is there to be read and feelings and sense receive and remember.

Has here something that binds and urges passengers to come back again. Is that the beauty of nature or history, or perhaps and one and other? On Knjaževcu are maintain sporting and cultural manifestations of history lesson and poetry, and it every July $13 \ldots$ There and monumental heritage of modern times, who also deserve special attention. When you take into consideration the entire cultural heritage on territory municipalities it can be concluded that the tourism potential worthy of respect. For rural tourism is very important to our existence of such tourist motives cultural character because they greatly complement are tourist offer tourists who choose one of the rural areas for stay. A very positive factor in the 
tourist industry of the village is this is that most of these cultural goods accessible and relatively close and some of them are in these same rural areas. The examples of following are rural settlements Kralje, Košutiće, Konjuhe etc.

\section{3. Rural Tourism}

The Municipality of Andrijevica has many resources for tourism development. With the inclusion of economic and non-economic activities, with an interest in tourism development, tourism should become a generator of growth of the municipality and of overall economic activity. Tourism related to the special interests include several aspects of tourism for which there is a corresponding demand is showing constant growth, with an expected tendency of even faster growth in the future. One form of development is precisely tourism in rural areas. First of all, it is particularly favourable conditions of preserved nature, with a mild climate, clean air, unpolluted rivers and Lake Bukumirsko, rich flora and fauna. These benefits are especially pronounced in mountainous rural areas. Stay in nature gives tourists the opportunity for walks, recreation, sports, organized excursions, go hunting and fishing, horseback riding, hiking, picking berries and herbs, and other recreational and leisure activities in the countryside.

Tourists for to show interest I can be included in for agricultural works. A large number of rural settlements municipal Andrijevica is located near the valuable cultural and historical monuments which tourists can visit organized. Exceptional cultural value has construction of traditional architecture the characteristics of a particular area, as well as the products of traditional crafts and handicrafts, through which he meets a rich heritage. In addition, it is possible to visit various exhibitions organized, which are organized at environment, particularly tourism events and traditional events, such as in a rural village Kralje, through which people learn about the customs and characteristics of rural life. The development of tourism in rural areas municipal Andrijevica, as an organized activity should be initiated by the Tourist agencies Andrijevica, which, together with travel agencies from the Montenegrin coast offered a room in the rural areas of the municipality. Contemporary of tourists seeking experiences providing a sense of intimacy with the natural resources and the local community. Each tourist destination that is intended to attract these visitors must protect its resources while emphasizing the sense of integration with the local community. In this process, the state has a very important role because it is responsible for the planning, design and policy development and prevention of excessive and irregular construction.

Characteristics of eco-destinations are reflected in the Wood [27], as well as in Dowling and Fennellz [28], through its preserved natural attractiveness within the protected landscape, low density development, where natural areas are abundant and where built areas do not dominate, the evidence that tourism does not harm nature (water flows, coastal areas, of wild animals), development of small local businesses, including stall with food and other types of craft enterprises owned by local people, places designed outdoor recreation, which are designed to protect sensitive resources (bicycle paths and forest trails, which benefit the local population), improvement of facilities for accommodation, hotels, restaurants and other businesses owned by local residents, in which there is a genuine hospitality of the friendly and motivated staff that favours, variety of local festivals and events that demonstrate the pride of the local community in relation to their natural environment and cultural heritage, clean public facilities shared by tourists and local residents, such as public showers and toilets.

Planning and management of tourism destinations in rural areas of the Municipality of Andrijevica in the future, we need to demonstrate the benefits of eco-tourism and rural areas 
of the municipality as a whole. Planning the construction of eco-destinations on are social and environmental factors, spatial planning, regulations preventing disruption of sensitive ecosystems, community participation in the process of developing a set of standards and long-term monitoring. Our research-based records on similar studies Plavša and Ratković [1], suggests that it must be stressed that a number of rural settlements municipal Andrijevica next addition what have a beautiful and untouched nature, rich gastronomy and authentic ethnographic heritage, have some very distinctive natural or cultural landmarks which would be factor the start of development of tourism. This holiday is not well-established rural settlements are affected by depopulation, and households are gradually becoming elderly. Tourism could be an important factor in staying young population in rural areas. In order to this happen it is necessary to invest in road and utility infrastructure and education of the local population, in order to encourage on active participation. It is necessary to also improving and marketing activity to rural settlements municipal Andrijevica, become recognizable in the tourist industry north-eastern Montenegro and the whole of Montenegro.

This primarily has to happen at the municipal, regional and finally national level. According to Hayek [29] and Renko et al [30] the basic preconditions for tourism development to village reflected primarily through the analysis of rural education in the host of this activity (standards of acceptance and accommodation of guests, the necessary hygienic requirements, method, quantity and quality providing service nutrition, behaviour towards guests and other necessary conditions for comfortable stay of tourists in rural household). Application of appropriate standardization and categorization of services (adequate housing conditions). Investments in infrastructure (road network, post ...). Providing are health care and the preservation and protection of the environment in order to prevent uncontrolled urbanization. Marketing and sales are of tourism products. On the other side towards Keller [31] and Smith et al [32], Tourism as a factor in the revitalization of the village of slowing migration to the city and the impact on young people staying on village, rejuvenation of rural population, and thus the improvement of the structure of the active working population increases production and allows for better marketing of agricultural products, handicrafts subject and products of traditional crafts, the hotel and out hotel spending.

The development of tourism in rural areas prevents the disturbance of the natural environment and the impact on the preservation of traditional folk architecture, ethnographic elements, distinctive way of life and labor, customs, folklore ... provide additional income and employment, the provision of tourism income rural areas with minimal investment by the farmers themselves. Municipality Andrijevica in the ethnological meaning is one of the very rich, diverse and interesting areas. Our research evidence based on similar studies Plavša and Ratković [1] shows that rural settlements municipal Andrijevica during many centuries evolved architecture typical for this region. It then not developed under the influence of an external, already is developed the residents of rural areas, as it suitable for them and how it was best for them. As a result of a long tradition of living in villages, a large number of old buildings have been preserved to this day. But these objects have not fallen into the shadow of oblivion, but still serve the people of this area to work and live and how they have served their ancestors centuries ago. This architecture is preserved in almost all villages municipal Andrijevica somewhere completely in most rural areas partly (Gnjili Potok, Kralje, Konjuhe, Cecune, Košutiće, Gračanica, Šekular ...). When we say objects here we think about the homes or chalets and ancillary facilities for life.

The houses are built exclusively of wood, or, the foundation of stone. Of the other objects are: the barns for grains, trap, dairy, baskets for corn, folds for sheep, and stables for livestock... It is performing adequate evaluation and presentation of ethnographic heritage so 
that it can be properly utilized. From gastronomic values should be singled out authentic food that residents of rural areas municipal Andrijevica genuine and use today as they did generations ago. These are the various types of cheese and cream, prosciutto, various brandy, juices and sweet from wild plants ... special milk specialty is "jardum". In addition to being found for Montenegrin environmentally friendly product, the winner of the 1996 awards world experts at the International Festival of healthy food in Milan. "Jardum" was classified, according estimated by the jury in the rare dairy products that have a positive and preventive effect on human health. Then, nettle, which is very rarely to be found on the menus, although they are delicious plant that can be prepared cooked and in many other ways. In the area beneath Komovi nettle the preparation with corn flour so they are in small pieces and cooked with flour allow cooling, after which it is usually eaten with sour milk or cow's milk. A real treat is full of vitamins and minerals. A particular specialty is the polenta and made from potatoes, wheat or corn flour and water, unlike traditional polenta that does not include potatoes. Crushed polenta is named after the fact that the potato (as the expression crushed) with hard wood with extended end.

This kind of polenta is made only in this area and we believe that is one of the crushed polenta indigenous foods is under Komovi. It is eaten mainly with cheese cream or greasy cheese and sour cream. Rural Gastronomic Specialties In addition to accommodations for now form the main offers from rural household's tourists who stay with them. Increasing agricultural production this gastronomic offer would be significantly increased, and continues to produce healthy and authentic food. In addition to placing ethnographic and culinary heritage in tourism function should be insisted on the largest possible contact with tourists and local population, in order to properly experienced traditional rural way of life. Thus, the basic conditions of rural tourism in municipality Andrijevica, refers to the necessary application of appropriate standardization and classification services, in particular the adequate conditions for accommodation. In the area of Mount Krivi Do built a mountain home, a centre for hikers who use the hiking trail Trešnjevik - Lisa- Krivi Do - Jelovica and at the same time to connect the region Andrijevice with Biograd worse which together make up a special tourist offer.

This facility capacity of 25 guests complements and enhances the hiking tourism offer. Project Eco - summer pastures is the first project in the field of sustainable tourism and the environment and is the initial phase of development of eco-tourism in the area municipal Andrijevica. The significance of this project is not only the achievement of economic and market evaluation of the effects of tourism potential but that it is the initial step in the development of healthy food, handicrafts and other activities that make up the basic precondition for stable development of tourism. Capacity summer pastures are: buildings hut / those 10 / content to rest and 5 persons, common space for organizing cultural and other activities. Reception with necessary facilities for provision of basic services and stalls trails for hikers of Komovi. Food is from local cuisine. Eco - home Trešnjevik at an altitude of $1.573 \mathrm{~m}$, with rooms for the issuance, restaurant with national cuisine. On Trešnjevik is also findings and pub "Krčma" with a summer terrace. Hotel Jelovica is situated on the banks of the river Jelovica, intended to accommodate hikers, has the ability to provide services, accommodation and food. In immediate vicinity is built towing the ski lift. Eco - Trešnjevik home at an altitude of $1,573 \mathrm{~m}$ with rooms for the issuance, restaurant with national cuisine. Motel "The Bridge" is located at the entrance to the Andrijevica intersection roads: the main road Berane-Andrijevica-Plav and Andrijevica-Mateševo-Podgorica. Facility has a restaurant space with a summer terrace and rooms for lodging, located is near the river crusting. Hotel "Komovi" is situated in the centre of Andrijevice has 100 beds and necessary support 
facilities for the provision of tourism services. In the immediate near object, there are significant sporting capacities: football stadium and small sports stadium.

Regional and town planning Andrijevica [8] suggest 5 area, or grouping of settlements on the territory of municipal Andrijevica from the point of valuation of natural and economic potential. Identifies are following areas: a central area- municipal centre Andrijevica is intended for industrial development, entrepreneurship, tourism, cultural and social activities. From the aspect of tourism development is underlined the importance of ski lift and construction of sports facilities to encourage the tourism development. Northern areaGradisnica is designed for development of forestry, agriculture and tourism and summer pastures, rural and eco tourism. On four mountain areas-Lisa, Gradisnica, Jelovica and Bačko Hill, foreseen is activation of 10 summer pastures village with 199 huts, of which 105 are in good condition. Favourable conditions for are construction of ski resorts the located in the mountainous area Jelovica and Jezerina. Part area (a move from Gnjili Potok to summer pastures Krivi Do and Jezerine) is intended for expansion of the Eco-Adventure Park Komovi.

The plan is to activate the resources for the construction of cottage settlements and holiday house in the area Jelovice and Gradišnjica in area the North. Exploitation of medicinal herbs, berries and mushrooms is planned to Lisa, Gradisnica and Jelovica. Western area- belonging to the mountainous area Komova, is a candidate for designation of a protected area that is the regional nature park, and is suitable for eco-tourism, hydropower utilization, and need the protection of hunting and fishing areas. This is the region of "Ecosummer pasture Stavna", which is the implementation of the first project in the field of sustainable tourism development. On the territory locations built Konjuhe is facility for processing of cheese, which is consistent with the assessment that this area suitable for the development of agro-tourism. Development of tourism eco-village on the model of mixed use Resorts is designed for the village Kosutici, Đulići and Jošanica. Part area (a move of Lakin Kose to Gnjili Potok stream) is intended for expansion of the Eco-Adventure Park Komovi, with Gnjili Potok in the zone Trešnjevik planned to build a secondary base for expansion Eco-Adventure Park Komovi. Selected the location of the first base of Adventure Park are with all necessary facilities. The plan stipulates that the Municipality of Andrijevica with Gnjili Stream in the zone Trešnjevik build a secondary base.

General amenities and proposed functional organization of second base of the park are to be formed of three parts: 1) visitor centre at the central square bases 2) mountain homeeco-lodge facilities with by 2-6 accommodation units with a central object (reception) and fitness / wellness studio and 3) Mountain tourist hotel with 50 beds, restaurant and services. The east area-Gračanica-Rijeka Marsenić characterized by an abundance of the mine, decorative stone and marble, which enables their processing, the required protective measures, it is intended for the development of rural tourism and pasture (in the mountains Balj and Sjekirica with 56 cottages, from which is 39 in serviceable condition) with the construction of the road to the pasture Mount Sjekirica, and then the agriculture and processing of agricultural products. The plan envisages the activation of resources to build a cottage villages and houses, primarily Balj in East the area. on the development direction, close to the highway and the available potential, Rijeka Marsenić conducive to economic development and entrepreneurship, with the existing furniture factory, and the family business. Southern area - Zeletin by vastness of largest, with are significant natural places to see for tourist development. The development of eco-tourism village modelled Mixed use Resort for a village Bojovići, Upper Luge, Ulotina, Cecuni and Kuti is intended for the development of mountain hunting and fishing tourism and livestock development with activation 11 summer pastures settlements in the mountains Zeletin and Asanac. Part area (direction of Lakine Kose 
to the border with Albania) is intended for expansion of the Eco-Adventure Park. The plan provides that the move Komovi future Regional Park, along the border of the municipality designated as wider zone of Eco-Adventure Park Komovi.

Within these spatial units should be dominant hiking, recreation, hunting development, and research tourism and mountain sports. Organization traditional summer pastures and placing the function of tourism along with providing accommodation services with higher quality standards should encourage the development of sport, mountain and hunting tourism, and the development of eco-tourism.

In the Municipality of Andrijevica in the past largest part population is engaged in livestock breeding, which was woven in everything life processes. The livestock living appeared specific mountain settlements of the twelfth century known as summer pastures [33]. Here are cattle breeders making its hut - apartments, as and other supporting structures of wood, where they stay a certain part of the year. Livestock the first stayed in the rural commune, and then on the mountain since the beginning of summer, when the vegetation period strongest, until the end of August, when they return to their villages. Beauty summer pastures is in its simplicity and functionality. With the hut were built and other outbuildings dairy, less individual hut that serve only to work around the milk. It is cooked milk, making cheese, cream and other dairy products. Idyllic summer pasture life (full of joy and happiness) best know those who have lived such a life. Children are the together play, while the senior very often in the evening in of hut gather on socializing. Here are women knitting, spun and combed wool, young play various games accompanied with song and story the morning [34]. Nutrition on summer pasture is pretty simple, but calories. Usually are eating barley, rye, buckwheat or corn bread. Beside him eating is lot of dairy products. Been cooking are potatoes, beans, cabbage, nettles and other greens. And pies were made with eggs and cheese. Meat the less food, while the for visitors rules gruel. Of the famous church holidays St. Peter and St. Elias come are many guests and relatives to visit, who are friendly hosts, served its chosen local specialties? This is an ideal opportunity to meet people.

Through songs and game and competitive spirit in competition and throw stone from the shoulder, long jump, the day progressed, merriment continued until dinner, while others are often spent the night on summer pasture in the morning and returning home. With impatience are anticipated new gatherings that are for these people were the most important events that have long memories. Today summer pastures in order to develop tourism and the tourism industry attracts nature lovers, and for those who want to learn about the traditional lifestyle of our ancestors, we should wait for better times [35].

According to the "Strategic Development Plan of the Municipality of Andrijevica 20122017" [36], in the municipality of Andrijevica there are excellent opportunities for tourism development summer pastures It is in the area of Municipalities are many summer pastures, on the mountain Lisa, on mount Asanac, on Gradišnjica, na mount Sjekirica, summer pastures on mount Štavna, on mount Jelovica, on mount Zeletin. During the winter and summer, here come the big number mountaineers from various countries. On nine mountain area is located 31 summer pasture settlement in which a total of 337 hut. Of the total number of Hut 127 is in relatively good condition, while 210 huts heavily damaged. The largest summer pasture settlements, with the largest number of huts, especially in favourable state are on mountainous area Gradišnica. The situation as regards the applicability of least favourable state is summer pasture settlements in the hills Lisa and Bačko Brdo. In terms of transport links, can be said that the road infrastructure to summer pastures very poor and in most cases can only come about off-road cars and tractors. As for electrification, it is evident that a very small number of areas, use electricity and on the mountain Balj and part Jelovice. 


\section{CONCLUSIONS}

Our research record based on similar researches Todorović [37], Ashley [38], English et al [39], Yague-Perales and March-Chorda [40], Reeder and Brown [41], pointed out several important conclusions, particularly in terms of renewable energy sources. Existing tourism and recreation supply is not sufficiently developed and affirmed nor organized and connected both within the scope the Municipality thus and with neighbouring municipalities. Tourism supply of the Municipality primarily the relies on a number of subjects already allocated and engaged in precisely those aspects of tourism that are base modern, potentially competitive tourism products (sports manifestations, hunting, fishing). However, in the Municipality of exist and many others, but under-utilized potential for tourism development.

Tourist attractiveness and quality of tourist offer are seen in the characteristics of the situation: tourist motivation, development of tourist sites and areas, as well as the connection between tourist motivation and tourist sites. In the municipality are various tourist motives that represent a good basis for the development of tourism, especially natural and created values. The main natural values of the river (Lim and its tributaries), streams and Bukumirsko Lake in the planning area are the potential for fishing and water sports. Bjelasica and Komovi their relief and climatic values represent attractive motivation for the development of tourism. They are rich in flora and fauna, habitats of large and small wildlife and have the potential to provide all kinds of recreation, sports and hunting tourism, but at present underutilized. The cultural and historic values and objects of the national architecture are only partially included in tourism and they have to be protect, valorise and adequately to in clued in network of tourist motives in the municipality.

Connectivity and accessibility of tourist sites and motifs in the municipality has decreased since, apart from a small number of local hiking routes, there is no regional system of pedestrian and bicycle paths that connect the main tourist sites, areas and recreational areas in the planning area, which, among tourist reduced and recreational quality of the municipality. Condition of roads is on some sections of very poor which reduces the accessibility and quality in the most attractive tourist resorts or potential accommodation facilities for rural tourism. Regardless the favourable opportunities for our development of tourism can be made the statement that tourism is not sufficiently developed in the municipality. Causes are more, but the most important are: the decision on the establishment of tourism organizations Andrijevica was not before 2011, the lack of proper infrastructure and accommodation, communal disorder, undeveloped water supply and sewage...

One of the prerequisites for the development of tourism is a good transport infrastructure. However, in the territory of municipal Andrijevica it is not adequate, but if we look at the state of roads in parts of different routes lead directly to rural communities, they require further improvement of the current situation. On the territory of municipal Andrijevice natural and anthropogenic values are distinguished group deployment and characteristics of complexity and complementarily. Natural values that have this area are indisputable, and can form the shaft of his tourism development. After are them mutually dependent and intertwined that makes them interesting and unique in time and space. Natural values are especially if you know that contemporary tourism trends emphasize the value of untouched nature.

Anthropogenic tourist values municipal Andrijevica in some way represent native tribes Vasojevića, given that here the remains of medieval determined, the remains of the monastery Čečevo and many churches that is the centre of spirituality. Today mentioned 
values represent the cultural and historical sites. These values can be seen as complementary to the wider area. Marketing affirmation municipal Andrijevica is one of the most important processes is the driving force for its tourist development. In doing so, it is necessary to distinguish between tourist valorisation of resources which is the physiognomy of tourism and marketing that the product is marketed. In this sense, must be enhanced all kinds of tourist propaganda, which affirmed the value (for example Eco-summer pasture Štavna), which would result to complete tourism development that would provide a profitable economic performance.

Regional and town planning municipality of Andrijevica [8] suggests 5 area, or grouping of settlements on the territory of municipal Andrijevica in terms of valuation of natural and economic potential. Act identifies the following areas: North area (settlements Sjenožeta, Prisoja, Slatina, Zabrđe, Trešnjevo and Trepča) within which the Western and north-western part of extends massif Bjelasica suitable for the development of forestry, agriculture and tourism.

West area (settlements Gnjili Potok, Kralje, Oblo Brdo, Božiće, Dulipolje, and Košutići) characterized developed tourism (summer pasture Štavna, Božička summer pasture, summer pasture Vulica ...) is suitable for the development of eco-tourism and hydropower development. Area central (municipal centre Andrijevica) is suitable for industrial development, social entrepreneurship, and cultural activities as well as tourism. Eastern area (Marsenić Rijeka settlements villages and Gračanica) and as rich deposits of minerals and decorative stone and marble has the capacity development in these areas, as well as the development of mountain hunting and fishing tourism. South area (settlements Andželati, Bojovići, Upper Luge, Đulići, Cecune, Ulotina, Kuti and Jošanica) is suitable for the development of mountain tourism, hunting and fishing, as well as for livestock development.

On the territory of the Municipality of Andrijevica some rural settlements established on former summer pastures and the process took a long time (approximately up to half of the twentieth century). Somewhere in areas of former summer pastures, now standing tourist resorts with modern cottages, while some summer pastures modernized so as to place huts built modern houses, while the rest of the retained everything that is characterized by idyllic summer pasture life.

The revival of summer pastures for development of tourism and the tourism industry in the municipality Andrijevica would be much wider, as nature lovers and those who want to learn about the traditional lifestyle of our ancestors. In last time, tourists from abroad are interested in this type of tourism. The customers would like to be placed not only in the rural village but to literally be involved in the life of the rural households. Yes in a particular way participate in rural activities. For them is attraction of watching mowers volunteer, riding on horseback. To visit the summer pastures of interesting sites that has every rural village municipality Andrijevice to live by the rules of the household and that of the village. Economic calculation is clear, rural households would not have too much to invest in the reception of guests. Tidy room by measured purity housewives, and everything else as well for his family, from are table, work commitments, lifestyle. So get in touch rural households and are customer is sold a jar of strawberry, raspberry, blueberry, and maybe a glass of sour milk, but accommodation and travel as a basis for the functioning of rural tourism no. Many authors, among them this time apostrophized Sharpley [42], Markandya et al [43], as well as Creaco and Querini [44] suggest among other things that today humanity faces many inequalities within and between nations, increasing hunger, poverty, disease and illiteracy. A major threat to our future, present, and environmental consequences of are reduction of ozone 
depletion, climate change, land degradation, deforestation, and loss of biodiversity and pollution of air, water and soil.

The gap in the development between industrialized countries and developing countries the deepened, and the number of poor the not decreased. More than a billion people in developing countries live without adequate food, medical care, education and housing, as people in developed countries use most of the world's resources. Tourism, with its position in the world economy, has a moral responsibility to take the lead in achieving the transition to sustainable development. Tourism has its own interest in it.

\section{References}

[1] Plavša J., Ratković S. S., Proceedings of the Department of Geography, Tourism and Hotel Management 36 (2007) 85-99.

[2] Živanović J., Pantić M., Specifics of rural areas in Serbia in dependence of touristic potentials, Available from: http://www.selo.co.rs (08.10 2013).

[3] Rajović G., Bulatović J., International Letters of Social and Humanistic Sciences 1(2014) 51-62.

[4] Office of Statistics Montenegro, Cenzus population 2003, Podgorica, 2005.

[5] Rajović G., Bulatović J., International Letters of Natural Sciences 3 (2013) 1-6.

[6] Rajović G., Journal of Road and Traffic Engineering 56 (3) (2010) 47-53.

[7] Rajović G., Journal of Road and Traffic Engineering 58 (2) (2012) 63-68.

[8] Municipality Andrijevica, Spatial urban development plan, Available from: http://www.andrijevica.me (15.10 2013).

[9] Radojičić B., Geography Montenegro-natural basis, “Unireks”, Nikšić, 1996.

[10] Rajović G., Bulatović J., International Letters of Social and Humanistic Sciences 6 (2013) 49-61.

[11] Municipality Andrijevica, Economic Potentials, Available from: http://www.andrijevica.me (18.10 2013).

[12] Bakić R., Upper Polimlje: nature, population and settlements, Nikšić: Geographical Institute of Philosophy Faculty; Andrijevica: Publishing house Komovi, 2005.

[13] Kićović M. D., Tourism and nature conservation Upper Polimlje, "University word", Nikšić, 1995.

[14] Rajović G., Scientific popular Proceedings "Land and People", Serbian Geographical Society 50 (2000) 75-81.

[15] Rajović G., Journal Mountainous paths 68 (2010) 34-35.

[16] Rajović G., Bulatović J., Russian Journal of Agricultural and Socio - Economic Sciences 4(16) (2013) 35-45.

[17] Rajović G., Journal industry 39 (3) (2011) 261-280.

[18] Rajović G., Journal of Sustainable Development Studies 2 (1)(2013) 24-68.

[19] Lutovac V. M., Andrijevica-characteristics of geographic location and factors of development, Establishment and development school Andrijevica from 1863 to 1973. Elementary School "Bajo Jojić", Andrijevica, 1973. 
[20] Vešović R., Tribe Vasojevići, "State Printing", Sarajevo, 1935.

[21] Dašić M., Vasojevići of mentioning to 1860. "National Book“, Belgrade, 1986.

[22] Rajović G., Bulatović J., Russian Journal of Agricultural and Socio - Economic Sciences 1 (13) (2013) 66-79.

[23] Tucović O., Stevanović R., Proceedings of the Geographical Institute "Jovan Cvijićc", Serbian Academy of Sciences and Arts 57(2007) 144.

[24] Regional Business Centre Berane, Profile municipal Andrijevica, Available from: http://www.andrijevica.me (20.10 2013).

[25] Group of authors, Monograph Montenegro, Literary Gazette, Belgrade, 1976.

[26] Deletić R., Komovi - Chronicle of time, Podgorica: Cultural educational community, Podgorica: Victory, 1995.

[27] Wood M. E., Ecotourism, UNEP, 2002.

[28] Dowling R. K., Fennellz D. A., Policy and Planning, Ecotourism policy and planning 1, 2003.

[29] Hajek T., Zemedelska Ekonomika - Praha 48 (12)(2002) 559-562.

[30] Renko S., Renko N., Polonijo T., Journal of Food Products Marketing 16(3) (2010) 309-324.

[31] Keller J., The importance of rural development in the 21st-century: persistence, sustainability and futures, The future of Australia's country towns, 2001, 19-31.

[32] Smith S., Davis N., Pike J., Journal of Extension 48(5) (2010) 1-11.

[33] Rajović G., Journal Economics 55 (1-2) (2009) 103-114.

[34] Summer pasture - Biogradska Gora National Parks of Montenegro, Available from: http://www.nparkovi.me (23.10 2013).

[35] Merry life in the summer pastures, Available from: http://www.politika.rs (24.10 2013).

[36] Municipality Andrijevica, Strategic Development Plan municipalities Andrijevica 2012 -2017, Available from:

http://www.andrijevica.me (24.10 2013).

[37] Todorović A., SASA 57 (2007) 213-222.

[38] Ashley C., The impacts of tourism on rural livelihoods: Namibia's experience, Overseas Development Institute, London, 2002.

[39] English D. B., Marcouille D. W., Cordell H. K., Society \& Natural Resources 13(3) (2000) 185-202.

[40] Yague-Perales R. M., March-Chorda I. S. I. D. R. E., Anatolia 15(2) (2004) 137-149.

[41] Reeder R. J., Brown D. M., Recreation, tourism, and rural well-being, DC: US Department of Agriculture, Economic Research Service, Washington, 2005.

[42] Sharpley R., Journal of Sustainable tourism 8(1) (2000) 1-19. 
[43] Markandya A., Taylor T., Pedroso S., Tourism and sustainable development: Lessons from recent World Bank experience, In International conference on tourism and sustainable economic development: macro and micro economic issues, CRENoS (Università di Cagliari e Sassari, Italy) and Fondazione Eni Enrico Mattei, Italy, Chia Laguna Hotel, Sardinia (19-20), 2003.

[44] Creaco S., Querini G., The role of tourism in sustainable economic development, In ERSA conference papers (No. ersa 03, p. 84), European Regional Science Association, 2003. 